\title{
MANUVER INOVASI PEMIMPIN DALAM MEMBERDAYAKAN PERILAKU KINERJA DENGAN DISIPLIN DAN KOMUNIKASI PEGAWAI (RISET PADA BADAN KEUANGAN DAERAH KABUPATEN SUKOHARJO)
}

\section{LEADER INNOVATION MANEUVER IN EMPOWERING PERFORMANCE BEHAVIOR WITH EMPLOYEE DISCIPLINE AND COMMUNICATION (RESEARCH AT THE REGIONAL FINANCE AGENCY OF SUKOHARJO REGENCY)}

\author{
Anita Dwi Putranti ${ }^{1}$, Mulyanto ${ }^{2}$ \\ Sekolah Tinggi Ilmu Ekonomi AUB Surakarta \\ Email : anitadwiputranti@gmail.com
}

\begin{abstract}
ABSTRAK
Penelitian ini bertujuan untuk mengetahui, menguji dan menganalisis pengaruh kepemimpinan, budaya organisasi, motivasi, kompetensi, kompensasi terhadap kinerja pegawai dengan disiplin kerja dan kepuasan kerja sebagai variabel intervening pada Badan Keuangan Daerah Kabupaten Sukoharjo. Teknik analisis data yang digunakan adalah analisis jalur (path analysis), dimana akan diuji dengan uji t, uji $\mathrm{F}$ dan uji $\mathrm{R}^{2}$, Correlations, pengaruh langsung dan pengaruh tidak langsung dan total pengaruh. Teknik pengumpulan data dengan menggunakan kuesioner, peneliti mengambil sampel sebanyak 60 responden. Hasil uji t menunjukan bahwa kepemimpinan, motivasi kerja dan kompensasi berpengaruh positif dan signifikan terhadap disiplin kerja dan budaya organisasi, kompetensi berpengaruh negatif dan signifikan terhadap disiplin kerja; kepemimpinan, budaya organisasi dan kompensasi berpengaruh positif dan signifikan terhadap kepuasan kerja dan motivasi kerja berpengaruh negatif dan signifikan terhadap kepuasan kerja. sedangkan kompetensi berpengaruh positif dan tidak signifikan terhadap kepuasan kerja; budaya organisasi, kompetensi, kompensasi, dan disiplin kerja berpengaruh positif dan signifikan terhadap kinerja dan kepuasan kerja berpengaruh negatif dan signifikan terhadap kinerja. kepemimpinan berpengaruh negatif dan tidak signifikan terhadap kinerja, dan motivasi kerja berpengaruh positif dan tidak signifikan terhadap kinerja pegawai. Dari hasil koefisien determinasi total dapat dijelaskan bahwa Nilai $\mathrm{R}^{2}$ total sebesar 0,996 ini berarti bahwa kinerja pegawai dijelaskan oleh variabel kepemimpinan, budaya organisasi, motivasi kerja, kompetensi, Kompensasi, disiplin kerja dan kepuasan kerja sebesar 99,6\% dan sisanya 0,4\% dijelaskan variabel lain diluar model penelitian sebagai contoh lingkungan kerja, komunikasi. Hasil analisis jalur menunjukkan bahwa jalur langsung kompensasi terhadap kinerja pegawai merupakan jalur yang dominan atau efektif untuk meningkatkan kinerja pegawai karena memiliki nilai kooefisien terbesar diantara yang lain.
\end{abstract}

Kata Kunci : kepemimpinan, budaya organisasi, motivasi, kompetensi, kompensasi, disiplin kerja, kepuasan kerja dan kinerja pegawai

\section{ABSTRACT}

This study aims to find out, test and analyze the influence of leadership, organizational culture, motivation, competence, compensation on employee performance with work discipline and job satisfaction as an intervening variable in the Regional Finance Agency of Sukoharjo Regency. The data analysis technique used is path analysis (path analysis), which will be tested by t test, $F$ test and $R 2$ test, Correlations, direct influence and indirect influence and total influence. Data collection techniques using a questionnaire, researchers took a sample of 60 respondents. The results of the t test show that leadership, work motivation and compensation have a positive and significant effect on work discipline and organizational culture, competence has a negative and significant effect on work discipline; leadership, organizational culture and compensation have a positive and significant effect on job satisfaction and work motivation has a negative and significant effect on job satisfaction. while competence has a positive and not significant effect on job satisfaction; organizational culture, competence, compensation, and work discipline have a positive and significant effect on job performance and satisfaction and have a significant negative effect on performance. leadership has a negative and not significant effect on performance, and work motivation has a positive and not significant effect on employee performance. From the results of the total coefficient of determination, it can be explained that the total $R 2$ value is 0.996 which means that employee performance is explained by leadership, organizational culture, work motivation, competence, compensation, work discipline and job satisfaction variables of $99.6 \%$ and the remaining $0.4 \%$ is explained other variables outside the research model as examples of work environment, communication. The results of the path analysis show that the direct path of compensation to employee performance is the dominant or effective path to improve employee performance because it has the largest cohesive value among the others.

Keywords : leadership, organizational culture, motivation, competence, compensation, work discipline, job satisfaction and employee performance 


\section{PENDAHULUAN}

Sumber daya manusia merupakan salah satu unsur yang sangat penting bagi instansi/perusahaan terutama dalam peningkatan kinerja instansi / perusahaan yang maksimal. Agar tujuan instansi/perusahaan dapat terwujud dan mendorong penyempurnaan berbagai sistem dalam pengelolaan sumber daya manusia yang mengarah pada bagaimana memberdayakan sumber daya manusianya. Perlu upaya pelaksanakan pengembangan SDM oleh setiap instansi/perusahaan dalam rangka mewujudkan pembangunan sumber daya manusia dalam setiap aspek kehidupan dalam pengelolaan pegawai.

Masalah peningkatan sumber daya manusia merupakan salah satu unsur yang sangat penting bagi instansi/perusahaan termasuk didalamnya adalah pegawai Badan Keuangan Daerah Kabupaten Sukoharjo. Oleh karena itu upaya perbaikan apapun yang dilakukan untuk meningkatkan kualitas kerja tidak akan memberikan sumbangan yang signifikan tanpa di dukung oleh pegawai yang profesional dan berkualitas. Kinerja pegawai dalam merencanakan dan melaksanakan pemberdayaan, merupakan faktor utama dalam pencapaian tujuan erat kaitannya dengan tugas dan tanggung jawab pegawai sebagai komponen instansi.

Kinerja adalah gambaran mengenai tingkat pencapaian pelaksanaan suatu kegiatan atau program atau kebijakan dalam mewujudkan sasaran, tujuan, misi dan visi instansi/perusahaan yang tertuang dalam rencana strategi suatu instansi/perusahaan. Mengacu pendapat tersebut di atas dapat diambil kesimpulan bahwa kinerja dapat didefinisikan sebagai hasil yang dicapai oleh seseorang menurut ukuran yang berlaku bagi pekerjaan yang bersangkutan (Handoko, 2011:35).

Perkembangan dinamika menuntut sumber daya manusia yang dapat memberikan pelayanan yang baik, sesuai tuntutan perkembangan dinamika masyarakat. Untuk mencapai itu semua diperlukan sumber daya manusia yang memiliki disiplin kerja yang tinggi, karena disiplin yang baik mencerminkan besarnya tanggungjawab pegawai terhadap tugas yang diberikan.

Discipline is systematic instruction given to disciples to train them as students in a craft or trade, or any other activity which they are supposed to perform, or to follow a particular code of conduct or "order". (http://en.wikipedia.org/wiki/discipline). Istilah disiplin (discipline) adalah kegiatan manajemen untuk menjalankan standar-standar instansi/perusahaan (Handoko, 2011 : 208). Disiplin merupakan bentuk pengendalian diri pegawai dan pelaksanaan yang teratur dan menunjukkan tingkat kesungguhan team kerja didalam sebuah instansi/perusahaan. Tindakan disipliner (disciplinary action) menurut suatu hukuman terhadap pegawai yang gagal memenuhi standar yang ditentukan.

Untuk dapat survive perusahaan atau organisasi harus mempunyai pegawai yang memiliki sikap yang baik dan semangat kerja yang tinggi sehingga ada rasa kepuasan dan loyalitas terhadap perusahaan. Sama dengan apa yang dikemukakan oleh Anas (2013: 2) bahwa pihak perusahaan harus dapat memahami perilaku pegawainya agar kebutuhan-kebutuhan pegawainya dapat terpenuhi, sehingga kepuasan kerja pegawai dapat terjaga. Kepuasan kerja sangat berpengaruh bagi kelangsungan kegiatan perusahaan. Menurut Yulharsari (2012:3) kepuasan kerja dapat meningkat jika pegawai memiliki rasa tanggung jawab untuk mengerjakan pekerjaannya secara maksimal sehingga dengan adanya rasa tanggung jawab yang tinggi dapat mewujudkan perilaku yang diarahkan pada tujuan guna mencapai sasaran akhir, yaitu tercapainya tujuan organisasi bersama.

Pemimpin dalam sebuah instansi/perusahaan apapun bentuk instansi/perusahaannya adalah tulang punggung dalam pengembangan instansi/perusahaan karena pemimpin merupakan pengendali dan pengarah jalannya instansi/perusahaan. Kepemimpinan akan berpengaruh terhadap motivasi dan kinerja pegawai, dengan kinerja pegawai Badan Keuangan Daerah Kabupaten Sukoharjo yang memadai memungkinkan timbulnya usaha peningkatan performa instansi. Bagi para pegawai, kinerja yang baik akan meningkatkan pelayanan masyarakat sesuai dengan tugas pegawai. Seperti yang dikemukakan oleh 
Toha (2008) bahwa "kepemimpinan adalah pola perilaku yang digunakan oleh seseorang pada saat orang tersebut mencoba mempengaruhi perilaku orang lain".

Budaya organisasi dapat mempengaruhi tingkah laku dari anggota instansi/perusahaan. Budaya organisasi adalah konsep yang marak dibicarakan dalam dasawarsa ini sebagai bagian dari ilmu manajemen. Menurut Robbin (2010 : 721), budaya organisasi merupakan suatu persepsi bersama yang dianut oleh anggota-anggota instansi/perusahaan lainnya. Suatu peraturan atau kewajiban yang harus dipenuhi oleh pegawai jika itu sudah diubah menjadi budaya maka hal tersebut akan memudahkan manajemen dalam mengatur pegawai yang ada dengan seminimal mungkin melakukan tindakan peringatan kepada pegawai.

Menurut Handoko (2010 : 77) mengatakan bahwa motivasi ialah dorongan kerja yang timbul pada diri seseorang untuk berperilaku dalam mencapai tujuan yang telah ditentukan. Siagian $(2010: 138)$ mengatakan yang dimaksud dengan motivasi adalah daya pendorong yang mengakibatkan seseorang anggota instansi/perusahaan mau dan rela untuk menggerakkan kemampuan dalam bentuk keahlian atau ketrampilan tenaga dan waktunya untuk menyelenggarakan berbagai kegiatan yang menjadi tanggungjawabnya dan menunaikan kewajibannya, dalam rangka pencapaian tujuan dan berbagai sasaran instansi/perusahaan yang telah ditentukan sebelumnya. Motivasi berasal dari kata latin "movere" yang berarti "dorongan atau daya penggerak". Motivasi adalah pemberian daya penggerak atau mendorong gairah kerja setiap individu pegawai agar mereka mau bekerja keras dan antusias untuk mencapai produktivitas kerja yang tinggi (Hasibuan; 2012: 109). .

Faktor lain yang berpengaruh terhadap disiplin kerja, kepuasan kerja dan kinerja adalah Kompensasi dan Kompetensi. Kompensasi merupakan timbal balik perusahaan terhadap kerja keras yang sudah dilakukan oleh pegawai. Setiap pegawai dalam instansi/perusahaan mempunyai keinginan untuk mendapatkan kompensasi yang sesuai dengan harapan pegawai dan apabila harapan terpenuhi maka para pegawai tersebut akan dengan senantiasa bersemangat dalam bekerja. Menurut Handoko (2014) dalam Putra (2014: 5), departemen personalia merancang dan mengadministrasikan kompensasi pegawai. Bila kompensasi yang diberikan secara benar, para pegawai lebih terpuaskan dan termotivasi untuk mencapai sasaran organisasi.

Sudarmanto (2010:87) mendefinisikan kompetensi sebagai kemampuan dan karakteristik yang dimiliki seorang Pegawai yang berupa pengetahuan, ketrampilan, dan sikap perilaku yang diperlukan dalam pelaksanaan tugas jabatannya, sehingga pegawai tersebut dapat melaksanakan tugasnya secara profesional, efektif dan efisien. Dengan adanya kompetensi pegawai di Badan Keuangan Daerah Kabupaten Sukoharjo yang baik yang sesuai dengan kebutuhan organisasi, maka pegawai akan senantiasa termotivasi dan melaksanakan kinerja secara maksimal.

Kesenjangan antara teori hubungan antara kepemimpian, budaya organisasi, motivasi kerja, kompensasi dan kompensasi terhadap disiplin kerja. kepuasan kerja dan kinerja dengan temuan hasil penelitian (teori gap) dan kesenjangan antara temuan hasil penelitian (riset gap) telah menimbulkan rasa ingin tahu untuk mengkaji lebih mendalam hubungan antar variabel tersebut. Atas dasar fenomena, landasan teori yang dikemukakan oleh para ahli maka akan diuji varibael tersebut, hal inilah yang mendorong peneliti untuk mengambil judul penelitian "Manuver Inovasi Pemimpin Dalam Perilaku Kinerja Dengan Membangun Disiplin Dan Komunikasi Pegawai (Riset Pada Badan Keuangan Daerah Kabupaten Sukoharjo) “ 


\section{HIPOTESIS}

Hipotesis adalah jawaban sementara terhadap rumusan masalah penelitian (Sugiyono, 2013: 151), Adapun hipotesis dalam penelitian pada Badan Keuangan Daerah Kabupaten Sukoharjo adalah sebagai berikut:

$\mathrm{H}_{1}$. Kepemimpinan berpengaruh signifikan terhadap disiplin kerja pada Badan Keuangan Daerah Kabupaten Sukoharjo.

$\mathrm{H}_{2}$. Budaya Organisasi berpengaruh signifikan terhadap disiplin kerja pada Badan Keuangan Daerah Kabupaten Sukoharjo.

$\mathrm{H}_{3}$. Motivasi Kerja berpengaruh signifikan terhadap disiplin kerja pada Badan Keuangan Daerah Kabupaten Sukoharjo.

$\mathrm{H}_{4}$. Kompetensi berpengaruh signifikan terhadap disiplin kerja pada Badan Keuangan Daerah Kabupaten Sukoharjo.

$\mathrm{H}_{5}$. Komunikasi berpengaruh signifikan terhadap disiplin kerja pada Badan Keuangan Daerah Kabupaten Sukoharjo.

$\mathrm{H}_{6}$. Kepemimpinan berpengaruh signifikan terhadap kepuasan kerja pada Badan Keuangan Daerah Kabupaten Sukoharjo.

$\mathrm{H}_{7}$. Budaya Organisasi berpengaruh signifikan terhadap kepuasan kerja pada Badan Keuangan Daerah Kabupaten Sukoharjo.

$\mathrm{H}_{8}$. Motivasi Kerja berpengaruh signifikan terhadap kepuasan kerja pada Badan Keuangan Daerah Kabupaten Sukoharjo.

H9. Kompetensi berpengaruh signifikan terhadap kepuasan kerja pada Badan Keuangan Daerah Kabupaten Sukoharjo.

$\mathrm{H}_{10}$. Komunikasi berpengaruh signifikan terhadap kepuasan kerja pada Badan Keuangan Daerah Kabupaten Sukoharjo.

$\mathrm{H}_{11}$. Kepemimpinan berpengaruh signifikan terhadap kinerja pegawai pada Badan Keuangan Daerah Kabupaten Sukoharjo

$\mathrm{H}_{12}$. Budaya Organisasi berpengaruh signifikan terhadap kinerja pegawai pada Badan Keuangan Daerah Kabupaten Sukoharjo.

$\mathrm{H}_{13}$. Motivasi kerja berpengaruh signifikan terhadap kinerja pegawai pada Badan Keuangan Daerah Kabupaten Sukoharjo.

$\mathrm{H}_{14}$. Kompetensi berpengaruh signifikan terhadap kinerja pegawai pada Badan Keuangan Daerah Kabupaten Sukoharjo.

$\mathrm{H}_{15}$. Kompensasi berpengaruh signifikan terhadap kinerja pegawai pada Badan Keuangan Daerah Kabupaten Sukoharjo.

$\mathrm{H}_{16}$. Disiplin kerja berpengaruh signifikan terhadap kinerja pegawai pada Badan Keuangan Daerah Kabupaten Sukoharjo.

$\mathrm{H}_{17}$. Kepuasan kerja berpengaruh signifikan terhadap kinerja pegawai pada Badan Keuangan Daerah Kabupaten Sukoharjo.

\section{METODE}

Penelitian ini merupakan penelitian total populasi Data yang digunakan adalah data primer dengan mengambil sejumlah 60 yang berarti seluruh anggota populasi dijadikan sebagai sampel responden. Penelitian ini menggunakan alat analisis berupa uji validitas, uji reliabilitas, uji linieritas, analisa jalur, analisa regresi linier berganda, uji t, uji $\mathrm{F}$ dan koefisien determinasi.

Analisis regresi jalur adalah, analisis jalur merupakan pengembangan langsung bentuk regresi berganda dengan tujuan untuk memberikan estimasi tingkat kepentingan (magnitude) dan signifikasi (significance) hubungan sebab akibat hipotetikal dalam seperangkat variabel. 
Excellent : Jurnal Manajemen, Bisnis dan Pendidikan

Vol 7, No 1 (2020) ; p.92-104; https://e-journal.stie-aub.ac.id/index.php/excellent

Hubungan kausalitas akan digunakan analisis jalur dan intervening. Pada penelitian ini variabel disiplin kerja dan kepuasan kerja ditempatkan sebagai variabel intervening untuk variabel kepemimpinan, budaya organisasi, motivasi kerja, kompetensi, dan kompensasi terhadap kinerja pegawai

Analisis regresi linear berganda digunakan untuk menganalisa pengaruh beberapa variabel bebas atau independen variabel $(\mathrm{X})$ terhadap satu variabel tidak bebas atau dependen variabel $(\mathrm{Y})$ sebagai berikut:

$$
\begin{aligned}
& Y_{1}=\beta_{1} X_{1+} \beta_{2} X_{2}+\beta_{3} X_{3}+\beta_{4} X_{4}+\beta_{5} X_{5}+e \ldots \ldots \ldots \text { (1) } \\
& Y_{2}=\beta_{6} X_{1+} \beta_{7} X_{2}+\beta_{8} X_{3}+\beta_{9} X_{4}+\beta_{10} X_{5}+e \ldots \ldots \ldots \text { (2) } \\
& Y_{3}=\beta_{11} X_{1+} \beta_{12} X_{2}+\beta_{13} X_{3}+\beta_{14} X_{4}+\beta_{15} X_{5}+\beta_{16} Y_{1}+\beta_{17} Y_{2}+e \ldots .
\end{aligned}
$$

\section{HASIL PENELITIAN}

Tabel IV.18.

Hasil Regresi Persamaan Pertama

Coefficients

\begin{tabular}{|ll|r|r|r|r|r|}
\hline & & \multicolumn{2}{|c|}{$\begin{array}{c}\text { Unstandardized } \\
\text { Coefficients }\end{array}$} & \multicolumn{2}{c|}{$\begin{array}{c}\text { Standardized } \\
\text { Coefficients }\end{array}$} & \\
\cline { 3 - 5 } Model & \multicolumn{1}{|c|}{ B } & Std. Error & \multicolumn{1}{c|}{ Beta } & \multicolumn{1}{c|}{ Sig. } \\
\hline 1 & (Constant) & 6,362 & 1,566 &, 062 &, 000 \\
& Kepemimpinan &, 852 &, 081 &, 880 & 10,512 &, 000 \\
& Budaya Organisasi &,- 164 &, 076 &,- 242 & $-2,150$ &, 036 \\
& Motivasi Kerja &, 199 &, 084 &, 296 & 2,358 &, 022 \\
& Kompetensi &,- 515 &, 123 &,- 566 & $-4,196$ &, 000 \\
& Kompensasi &, 304 &, 113 &, 397 & 2,704 &, 009 \\
\hline
\end{tabular}

a. Dependent Variable: Disiplin Kerja

Tabel IV.19.

Hasil Regresi Persamaan Kedua

Coefficients

\begin{tabular}{|ll|r|r|r|r|r|}
\hline \multirow{2}{*}{ Model } & \multicolumn{2}{|c|}{$\begin{array}{c}\text { Unstandardized } \\
\text { Coefficients }\end{array}$} & \multicolumn{2}{c|}{$\begin{array}{c}\text { Standardized } \\
\text { Coefficients }\end{array}$} & \multirow{2}{*}{} \\
\cline { 3 - 5 } & & \multicolumn{1}{|c|}{ B } & Std. Error & \multicolumn{1}{c|}{ Beta } & \multicolumn{1}{c|}{ Sig. } \\
\hline 1 & (Constant) & 3,122 & 1,581 & & 1,975 &, 053 \\
& Kepemimpinan &, 209 &, 082 &, 187 & 2,555 &, 013 \\
& Budaya Organisasi &, 225 &, 077 &, 288 & 2,916 &, 005 \\
& Motivasi Kerja &,- 564 &, 085 &,- 729 & $-6,620$ &, 000 \\
& Kompetensi &, 201 &, 124 &, 192 & 1,628 &, 109 \\
& Kompensasi &, 805 &, 114 &, 911 & 7,085 &, 000 \\
\hline
\end{tabular}

a. Dependent Variable: Kepuasan Kerja

Tabel IV.20.

\begin{tabular}{|c|c|c|c|c|c|c|}
\hline \multirow{2}{*}{\multicolumn{2}{|c|}{ Model }} & \multicolumn{2}{|c|}{$\begin{array}{l}\text { Unstandardized } \\
\text { Coefficients }\end{array}$} & \multirow{2}{*}{$\begin{array}{c}\text { Standardized } \\
\text { Coefficients } \\
\text { Beta } \\
\end{array}$} & \multirow[b]{2}{*}{$\mathrm{t}$} & \multirow[b]{2}{*}{ Sig. } \\
\hline & & B & Std. Error & & & \\
\hline \multirow[t]{8}{*}{1} & (Constant) & ,230 & 1,321 & &, 174 & 863 \\
\hline & Kepemimpinan &,- 161 & ,104 &,- 135 & $-1,546$ & , 128 \\
\hline & Budaya Organis asi & ,296 & 061 & ,357 & 4,869 & 000 \\
\hline & Motivasi Kerja & 048 & 083 & 058 &, 577 & ,566 \\
\hline & Kompetensi & ,339 & ,103 & ,305 & 3,306 & ,002 \\
\hline & Kompensasi &, 537 & , 116 &, 572 & 4,607 & ,000 \\
\hline & Dis iplin Kerja & ,311 & 097 & ,253 & 3,185 & ,002 \\
\hline & Kepuas an Kerja &,- 386 & 097 &,- 364 & $-4,000$ &, 000 \\
\hline
\end{tabular}

Hasil Regresi Persamaan ketiga

Coefficients $s^{a}$

a. Dependent Variable:Kinerja 
Tabel IV.21

Hasil Uji F Persamaan ketiga

ANOVA $^{\mathrm{b}}$

\begin{tabular}{|c|c|c|c|c|c|c|}
\hline Model & & $\begin{array}{c}\text { Sum of } \\
\text { Squares }\end{array}$ & df & Mean Square & $\mathrm{F}$ & Sig. \\
\hline \multirow[t]{3}{*}{1} & Regression & 351,114 & 7 & 50,159 & 82,187 &, $000^{a}$ \\
\hline & Residual & 31,736 & 52 & ,610 & & \\
\hline & Total & 382,850 & 59 & & & \\
\hline
\end{tabular}

a. Predictors: (Constant), Kepuasan Kerja, Disiplin Kerja, Motivasi Kerja, Budaya

Organisasi, Kepemimpinan, Kompetensi, Kompensasi

b. Dependent Variable: Kinerja

Tabel IV.22

Koefisien Determinan $\left(\mathrm{R}^{2}\right)$ Persamaan Pertama

\begin{tabular}{|l|r|r|r|r|}
\multicolumn{7}{c|}{ Model Summary } \\
\hline Model & $\mathrm{R}$ & R Square & $\begin{array}{c}\text { Adjusted } \\
\text { R Square }\end{array}$ & $\begin{array}{r}\text { Std. Error of } \\
\text { the Estimate }\end{array}$ \\
\hline 1 &, $865^{\mathrm{a}}$ &, 748 &, 725 & 1,091 \\
\hline
\end{tabular}

a. Predictors: (Constant), Kompens asi, Kepemim pinan, Budaya Organis asi, Motivasi Kerja, Kompetensi

Tabel IV.23

Koefisien Determinan $\left(\mathrm{R}^{2}\right)$ Persamaan Kedua

\begin{tabular}{|l|r|r|r|r|}
\multicolumn{1}{c}{ Model Summary } \\
\hline Model & $\mathrm{R}$ & R Square & $\begin{array}{c}\text { Adjusted } \\
\text { R Square }\end{array}$ & $\begin{array}{r}\text { Std. Error of } \\
\text { the Estimate }\end{array}$ \\
\hline 1 &, $898^{\mathrm{a}}$ &, 807 &, 789 & 1,101 \\
\hline
\end{tabular}

a. Predictors: (Constant), Kompens asi, Kepemimpinan, Budaya Organis asi, Motivasi Kerja, Kompetensi

Tabel IV.24

Koefisien Determinan $\left(\mathrm{R}^{2}\right)$ ketiga

Model Summary

\begin{tabular}{|l|r|r|r|r|}
\hline Model & R & R Square & $\begin{array}{c}\text { Adjusted } \\
\text { R Square }\end{array}$ & $\begin{array}{r}\text { Std. Error of } \\
\text { the Estimate }\end{array}$ \\
\hline 1 &, $958^{\mathrm{a}}$ &, 917 &, 906 &, 781 \\
\hline
\end{tabular}

a. Predictors: (Constant), Kepuas an Kerja, Disiplin Kerja, Motivasi Kerja, Budaya Organis asi, Kepemimpinan, Kompetensi, Kompensasi

Tabel IV.26

Koefisien Korelasi

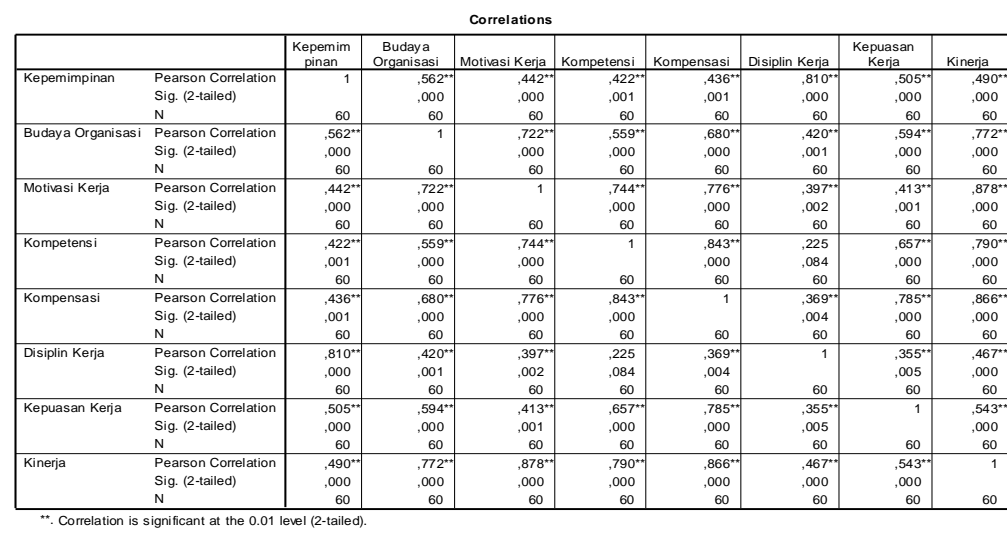


Berdasarkan hasil analisa jalur dapat diperoleh hasil sbb:

Persamaan 1 yaitu :

$Y_{1}=0,880 X_{1}-0,242 X_{2}+0,296 X_{3}-0,566 X_{4}+0,397 X_{5}+\epsilon$

Sig $(0,000)^{* *}(0,036)^{* *}(0,022)^{* *}(0,000)^{* *} \quad(0,009)^{* *}$

persamaan 2 yaitu :

$\mathrm{Y}_{2}=0,187 \mathrm{X}_{1}+0,288 \mathrm{X}_{2}-0,729 \mathrm{X}_{3}+0,192 \mathrm{X}_{4}+0,911 \mathrm{X}_{5}+\epsilon$

Sig $(0,013)^{* *}(0,005)^{* *}(0,000)^{* *}(0,109) \quad(0,000)^{* *}$

persamaan 3 yaitu :

$\mathrm{Y}_{3}=-0,136 \mathrm{X}_{1}+0,357 \mathrm{X}_{2}+0,058 \mathrm{X}_{3}+0,305 \mathrm{X}_{4}+0,572 \mathrm{X}_{5 .}+0,253 \mathrm{X}_{6}-0,364 \mathrm{X}_{7}+\epsilon$

Sig $(0,128) \quad(0,000)^{* *}(0,566) \quad(0,002)^{* *}(0,000)^{* *}(0,002)^{* *}(0,000)^{* *}$

\section{Model Hasil Analisis:}

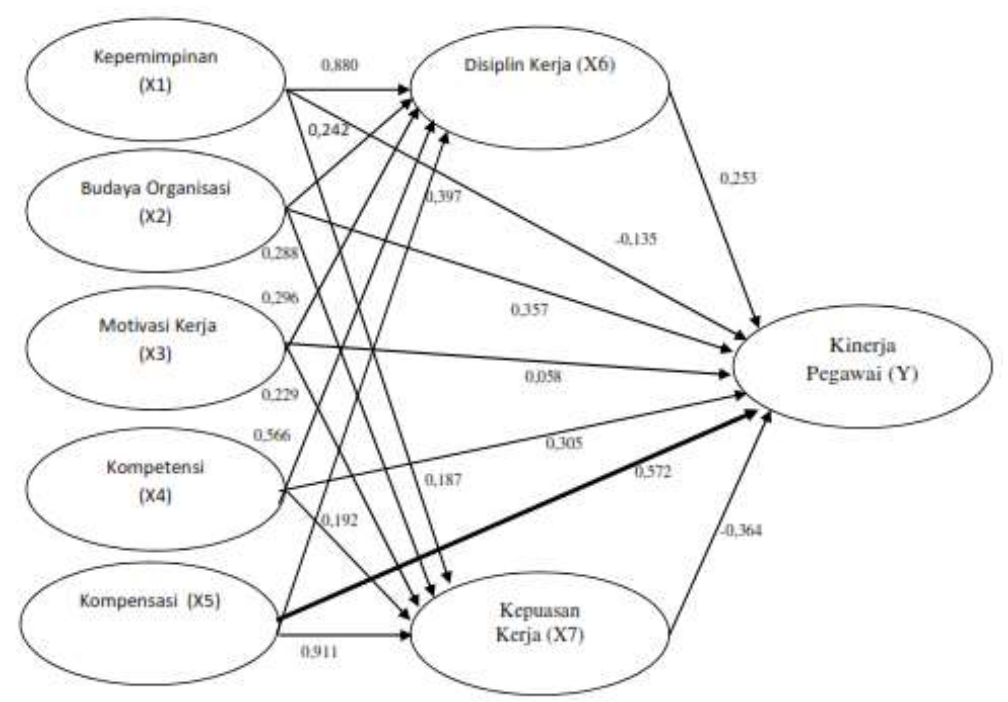

Gambar IV.1

Pengaruh Langsung dan Tidak Langsung

\section{PEMBAHASAN}

1. Pengaruh Kepemimpinan terhadap Kinerja pegawai melalui Disiplin Kerja dan Kepuasan kerja.

Pengaruh langsung Kepemimpinan signifikan terhadap kinerja pegawai di Badan Keuangan Daerah Kabupaten Sukoharjo, hal ini menunjukkan bahwa variable kepemimpinan berpengaruh positif terhadap kinerja pegawai di Badan Keuangan Daerah Kabupaten Sukoharjo, apabila kepemimpinan ditingkatkan maka kinerja pegawai di Badan Keuangan Daerah Kabupaten Sukoharjo akan meningkat secara bermakna.

Analisis jalur ini menunjukkan bahwa penggunaan variabel intervening Disiplin Kerja dan Kepuasan kerja dalam rangka peningkatan kinerja, untuk variabel kepemimpinan adalah kurang efektif, karena pengaruh tidak langsung menghasilkan pengaruh yang kurang efektif dari pada pengaruh langsung. Karena pengaruh langsung kepemimpinan terhadap kinerja pegawai lebih 
efektif, maka langkah-langkah untuk meningkatkan perilaku kinerja secara kongkrit, dapat ditingkatkan dengan melihat nilai indikator tertinggi uji validitas kepemimpinan yaitu terletak pada item pernyataan $2,3,1,5$, dan $4 .:$

a. Pimpinan memberikan peluang konsultasi kepada bawahan dalam penyelesaian pekerjaan.

b. Partisipasi pimpinan dalam pengembangan instansi sangat besar

c. Pimpinan saya selalu memberikan instruksi dan arahan yang mudah dipahami dalam pelaksanaan tugas.

d. Pimpinan mempunyai kemampuan yang baik dalam pengendalian bawahan

e. Pimpinan saya melakukan delegasi wewenang dengan penuh sesuai tugas pokok pekerjaan

2. Pengaruh Budaya Organisasi terhadap Kinerja pegawai melalui Disiplin Kerja dan Kepuasan kerja.

Pengaruh langsung Budaya Organisasi signifikan terhadap kinerja pegawai di Badan Keuangan Daerah Kabupaten Sukoharjo, hal ini menunjukkan bahwa variable Budaya Organisasi berpengaruh positif terhadap kinerja pegawai di Badan Keuangan Daerah Kabupaten Sukoharjo, apabila Budaya Organisasi ditingkatkan maka kinerja pegawai di Badan Keuangan Daerah Kabupaten Sukoharjo akan meningkat.

Analisis jalur ini menunjukkan bahwa penggunaan variabel intervening Disiplin Kerja dan Kepuasan kerja dalam rangka peningkatan kinerja, untuk variabel Budaya Organisasi adalah kurang efektif, karena pengaruh tidak langsung menghasilkan pengaruh yang kurang efektif dari pada pengaruh langsung. Karena pengaruh langsung Budaya Organisasi terhadap kinerja pegawai lebih efektif, maka langkah-langkah untuk meningkatkan perilaku kinerja secara kongkrit, dapat ditingkatkan dengan melihat nilai indikator tertinggi uji validitas Budaya Organisasi yaitu terletak pada item pernyataan 4, 3, 2, 5 dan 1:

a. Adanya keadilan pimpinan kepada setiap pegawai dalam menjalankan tugas yang diberikan.

b. Adanya Partisipasi pegawai dilingkungan dinas dalam pelaksanaan kegiatan yang dibebankan kepada setiap pegawai.

c. Setiap pegawai mempunyai komitmen pada peraturan dan ketentuan yang ada.

d. Pegawai selalu mentaati peraturan yang sudah ditetapkan

e. Sistem penghargaan pegawai yang diberikan selama ini sesuai dengan kompetensi pegawai.

3. Pengaruh Motivasi Kerja terhadap Kinerja pegawai melalui Disiplin Kerja dan Kepuasan kerja.

Pengaruh langsung Motivasi Kerja signifikan terhadap kinerja pegawai di Badan Keuangan Daerah Kabupaten Sukoharjo, hal ini menunjukkan bahwa variable Motivasi Kerja berpengaruh positif terhadap kinerja pegawai di Badan Keuangan Daerah Kabupaten Sukoharjo dan merupakan jalur paling dominan, apabila Motivasi Kerja ditingkatkan maka kinerja pegawai di Badan Keuangan Daerah Kabupaten Sukoharjo akan meningkat secara bermakna.

Analisis jalur ini menunjukkan bahwa penggunaan variabel intervening Disiplin Kerja dan komitmen dalam rangka peningkatan kinerja, untuk variabel Motivasi Kerja adalah kurang efektif, karena pengaruh tidak langsung menghasilkan pengaruh yang kurang efektif dari pada pengaruh langsung. Karena pengaruh langsung Motivasi Kerja terhadap kinerja pegawai lebih efektif, maka langkah-langkah untuk meningkatkan perilaku kinerja secara kongkrit, dapat ditingkatkan dengan melihat nilai indikator tertinggi uji validitas Motivasi Kerja yaitu terletak pada item pernyataan 2, 4,

5, 3 dan 1:

a. Kondisi lingkungan kerja dari aspek keamanan sangat mendukung dalam bekerja.

b. Penghargaan Badan Keuangan Daerah Kabupaten Sukoharjo atas kinerja membuat saya lebih giat lagi dalam bekerja.

c. Bidang kerja yang dikerjakan sangat menarik dan memberikan tantangan untuk meningkatkan aktualisasi diri. 
d. Hubungan sosial yang baik di kantor membuat saya nyaman dalam bekerja.

e. Secara fisiologis gaji yang diterima sudah baik dan layak.

4. Pengaruh Kompetensi terhadap Kinerja pegawai melalui Disiplin Kerja dan Kepuasan kerja.

Pengaruh langsung Kompetensi signifikan terhadap kinerja pegawai di Badan Keuangan Daerah Kabupaten Sukoharjo, hal ini menunjukkan bahwa variable kompetensi berpengaruh positif terhadap kinerja pegawai di Badan Keuangan Daerah Kabupaten Sukoharjo, apabila kompetensi ditingkatkan maka kinerja pegawai di Badan Keuangan Daerah Kabupaten Sukoharjo akan meningkat.

Analisis jalur ini menunjukkan bahwa penggunaan variabel intervening Disiplin Kerja dan Kepuasan kerja dalam rangka peningkatan kinerja, untuk variabel kompetensi adalah kurang efektif, karena pengaruh tidak langsung menghasilkan pengaruh yang kurang efektif dari pada pengaruh langsung. Karena pengaruh langsung kompetensi terhadap kinerja pegawai lebih efektif, maka langkah-langkah untuk meningkatkan perilaku kinerja secara kongkrit, dapat ditingkatkan dengan melihat nilai indikator tertinggi uji validitas kompetensi yaitu terletak pada item pernyataan 5, 2, 4, 1 dan 3:

a. Pegawai melakukan pekerjaan dengan cepat dan cermat.

b. Pegawai mudah memahami tugas yang diberikan secara tertulis maupun lisan

c. Pegawai menguasai teknologi dengan baik sehingga tugas dapat terselesaikan dengan cepat

d. Pegawai selalu mampu menyelesaikan tugas tepat waktu.

e. Dengan pendidikan yang tinggi akan lebih mudah naik pangkat

5. Pengaruh Kompensasi terhadap Kinerja pegawai melalui Disiplin Kerja dan Kepuasan kerja.

Pengaruh langsung Kompensasi signifikan terhadap kinerja pegawai di Badan Keuangan Daerah Kabupaten Sukoharjo, hal ini menunjukkan bahwa variable Kompensasi berpengaruh positif terhadap kinerja pegawai di Badan Keuangan Daerah Kabupaten Sukoharjo, apabila Kompensasi ditingkatkan maka kinerja pegawai di Badan Keuangan Daerah Kabupaten Sukoharjo akan meningkat.

Analisis jalur ini menunjukkan bahwa penggunaan variabel intervening Disiplin Kerja dan Kepuasan kerja dalam rangka peningkatan kinerja, untuk variabel Kompensasi adalah kurang efektif, karena pengaruh tidak langsung menghasilkan pengaruh yang kurang efektif dari pada pengaruh langsung. Karena pengaruh langsung Kompensasi terhadap kinerja pegawai lebih efektif, maka langkah-langkah untuk meningkatkan perilaku kinerja secara kongkrit, dapat ditingkatkan dengan melihat nilai indikator tertinggi uji validitas Kompensasi yaitu terletak pada item pernyataan 3, 4, 2, 5 dan 1:

a. Setiap pegawai menerima insentif berkaitan dengan pekerjaan di luar jam kerja.

b. Bonus yang diberikan Badan Keuangan Daerah Kabupaten Sukoharjo sesuai dengan prestasi.

c. Upah yang diterima pegawai sudah sesuai.

d. Fasilitas yang diberikan instansi sudah sesuai dengan tupoksi masing - masing pegawai

e. Gaji yang diterima pegawai sudah sesuai dengan tupoksi pegawai

\section{PENUTUP}

\section{Simpulan}

Berdasarkan hasil analisa data dan pengujian hipotesis yang telah dilakukan dapat ditarik kesimpulan:

1. Berdasarkan hasil uji t menunjukan bahwa:

a. Variabel Kepemimpinan, Motivasi Kerja dan Kompensasi berpengaruh positif dan signifikan terhadap Disiplin Kerja sedangkan Budaya Organisasi, Kompetensi berpengaruh negatif dan signifikan terhadap Disiplin Kerja di Badan Keuangan Daerah Kabupaten Sukoharjo. 
b. Kepemimpinan, Budaya Organisasi dan Kompensasi berpengaruh positif dan Signifikan terhadap Kepuasan Kerja sedangkan Motivasi Kerja berpengaruh negatif dan Signifikan terhadap Kepuasan Kerja. Sedangkan Kompetensi berpengaruh positif dan tidak Signifikan terhadap Kepuasan Kerja

c. Variabel Budaya Organisasi, Kompetensi, Kompensasi, dan Disiplin Kerja berpengaruh positif dan Signifikan terhadap Kinerja sedangkan Kepuasan Kerja berpengaruh negatif dan Signifikan terhadap Kinerja. Kepemimpinan berpengaruh negatif dan tidak Signifikan terhadap Kinerja, sedangkan Motivasi Kerja berpengaruh positif dan tidak Signifikan terhadap Kinerja.

2. Berdasarkan hasil uji F menunjukkan bahwa:

Hasil uji $F$ pada persamaan ketiga diketahui besarnya nilai $F=82,187$ signifikansi $0,000<0,05$. Sehingga dapat disimpulkan secara bersama-sama variabel kepemimpinan, budaya organisasi, motivasi kerja, kompetensi, Kompensasi, disiplin kerja dan kepuasan kerja berpengaruh signifikan terhadap Kinerja pegawai di Badan Keuangan Daerah Kabupaten Sukoharjo..

3. Hasil uji dengan analisis jalur menunjukkan:

a. Pengaruh Kepemimpinan terhadap Kinerja pegawai lebih besar dibanding pengaruh Kepemimpinan terhadap Kinerja pegawai melalui disiplin kerja dan kepuasan kerja.

b. Pengaruh budaya organisasii terhadap Kinerja pegawai lebih besar dibanding pengaruh budaya organisasii terhadap Kinerja pegawai melalui disiplin kerja dan kepuasan kerja.

c. Pengaruh motivasi kerja terhadap Kinerja pegawai lebih besar dibanding pengaruh motivasi kerja terhadap Kinerja pegawai melalui disiplin kerja dan kepuasan kerja.

d. Pengaruh kompetensi terhadap kinerja pegawai lebih besar dibanding pengaruh kompetensi terhadap kinerja pegawai melalui disiplin kerja dan kepuasan kerja.

e. Pengaruh Kompensasi terhadap Kinerja pegawai lebih besar dibanding pengaruh Kompensasi terhadap Kinerja pegawai melalui disiplin kerja dan kepuasan kerja.

f. Dari analisis jalur diketahui jalur langsung pengaruh kompensasi terhadap kinerja pegawai merupakan jalur yang paling dominan atau paling efektif untuk meningkatkan kinerja pegawai karena memiliki nilai kooefisien terbesar diantara yang lain

4. Dari hasil koefisien determinasi total dapat dijelaskan bahwa Nilai $\mathrm{R}^{2}$ total sebesar 0,996 ini berarti bahwa kinerja pegawai di Badan Keuangan Daerah Kabupaten Sukoharjo dijelaskan oleh variabel kepemimpinan, budaya organisasii, motivasi kerja, kompetensi, Kompensasi, disiplin kerja dan kepuasan kerja sebesar 99,6\% dan sisanya 0,4\% dijelaskan variabel lain diluar model penelitian sebagai contoh lingkungan kerja, komunikasi, kompensasi.

\section{Saran}

Berdasarkan hasil penelitian di atas, maka hal yang dapat disarankan untuk Badan Keuangan Daerah Kabupaten Sukoharjo adalah sebagai berikut:

1. Karena kompensasi merupakan variabel paling efektif dan dominan secara langsung dalam mempengaruhi kinerja pegawai di Badan Keuangan Daerah Kabupaten Sukoharjo. Untuk itu peneliti menyarankan Badan Keuangan Daerah Kabupaten Sukoharjo meningkatkan kompensasi untuk pegawai dalam upaya meningkatkan kinerja dengan langkah-langkah kongkrit :

1) Setiap pegawai menerima insentif berkaitan dengan pekerjaan di luar jam kerja.

2) Bonus yang diberikan Badan Keuangan Daerah Kabupaten Sukoharjo sesuai dengan prestasi.

3) Upah yang diterima pegawai sudah sesuai.

4) Fasilitas yang diberikan instansi sudah sesuai dengan tupoksi masing - masing pegawai

5) Gaji yang diterima pegawai sudah sesuai dengan tupoksi pegawai

2. Budaya Organisasi juga perlu ditingkatkan, karena kepemimpinan merupakan variabel yang efektif berikutnya dalam mempengaruhi kinerja pegawai di Badan Keuangan Daerah Kabupaten Sukoharjo. 
Untuk itu peneliti menyarankan Badan Keuangan Daerah Kabupaten Sukoharjo meningkatkan Budaya Organisasi dalam upaya meningkatkan kinerja dengan langkah-langkah kongkrit :

1) Adanya keadilan pimpinan kepada setiap pegawai dalam menjalankan tugas yang diberikan.

2) Adanya Partisipasi pegawai dilingkungan dinas dalam pelaksanaan kegiatan yang dibebankan kepada setiap pegawai.

3) Setiap pegawai mempunyai komitmen pada peraturan dan ketentuan yang ada.

4) Pegawai selalu mentaati peraturan yang sudah ditetapkan.

3. Dalam rangka meningkatkan kinerja pegawai di Badan Keuangan Daerah Kabupaten Sukoharjo sebaiknya juga meningkatkan Kompetensi untuk meningkatkan kinerja pegawai dengan langkahlangkah kongkrit :

1) Pegawai melakukan pekerjaan dengan cepat dan cermat.

2) Pegawai mudah memahami tugas yang diberikan secara tertulis maupun lisan

3) Pegawai menguasai teknologi dengan baik sehingga tugas dapat terselesaikan dengan cepat

4) Pegawai selalu mampu menyelesaikan tugas tepat waktu.

5) Dengan pendidikan yang tinggi akan lebih mudah naik pangkat.

\section{DAFTAR PUSTAKA}

Achmad, 2018. Pengaruh Motivasi Kerja Dan Kompetensi Terhadap Kinerja Pegawai Melalui Disiplin Kerja Dinas Pendidikan Kabupaten Takalar. Jurnal Mirai Management Volume 3 No.2 2018

Arikunto, Suharsimi. 2010. Metode Penelitian. Rineka Cipta. Jakarta

Ambar Teguh Sulistiyani, 2012. Memahami Good Governance: Dalam Perspektif Sumber Daya Manusia, Yogyakarta: Penerbit Gava Media.

As'ad, Mohamad. 2013. Psikologi Industri. Edisi keempat. Yogyakarta. Liberty

Davis, Keith dan John W. Newstrom, 2013. Perilaku Dalam Organisasi. Jilid 2 Edisi Ketujuh, Jakarta : Penerbit PT Erlangga.

Farid dkk, 2016. Pengaruh Motivasi Kerja Terhadap Kedisiplinan Dan Kinerja Pegawai Pt. Pln Distribusi Jawa Timur Area Malang. Jurnal Administrasi Bisnis (JAB) Vol. 32 No. 1 Maret 201675 administrasi bisnis.studentjournal.ub.ac.id

Fuad, Mas'ud. 2015. Survai Diagnosis Organisasional Konsep \& Aplikasi. Badan Penerbit Universitas Diponegoro. Semarang

Ghozali Imam. 2011. Aplikasi Analisis Multivariet dengan Program SPSS. Semarang: Badan Penerbit Undip.

Gibson, James L, John M Ivancevich. 2009, Organisasi dan Manajemen: Perilaku, Struktur, Proses, Edisi 4, TerjemahanDjoerban Wahid, penerbitErlangga, Jakarta.

Handoko, Hani, 2010. Manajemen Personalia dan Sumber Daya Manusia, BPFE UGM, Yogyakarta.

Handoko Hani dkk. 2014. Strategi Organisasi. Yogyakarta : Amara Books.

Hasibuan Melayu SP. 2010. Organisasi dan Motivasi. Dasar Peningkatan Produktifitas. Jakarta: Bumi Aksara.

Hasibuan, Malayu, 2012. Manajemen Sumber Daya Manusia: Pengadaan, Pengembangan, Pengkompensasian. Jakarta: Rajawali Press. 
Excellent : Jurnal Manajemen, Bisnis dan Pendidikan

Vol 7, No 1 (2020) ; p.92-104; https://e-journal.stie-aub.ac.id/index.php/excellent

Kartono Kartini, 2015. Pemimpin dan Kepemimpinan. Jakarta: PT. Raja Grafindo Persada.

Kreither dan Kinicki. 2005. Organizational Behavior (Perilaku Organisasi). Jakarta : Salemba empat.

Kotter J.P. and Heskett J.L., 2011, “Corporate Culture and Performance”, The Free Press, New York.

Kumarawati, 2017. Penggaruh Motivasi Terhadap Disiplin Dan Kinerja Pegawai Pada Sekretariat Daerah Kota Denpasar. JAGADHITA:Jurnal Ekonomi \& Bisnis, Vol. 4, No 2. September 2017,Hal 6375

Lukiyana, 2016. Pengaruh Kompensasi Dan Fasilitas Kerja Terhadap Kinerja Guru Dengan Disiplin Kerja Sebagai Variabel Intervening Pada Tk Misi Bagi Bangsa Sejakarta. Media Manajemen Jasa ISSN 2502-3632 (Online) ISSN 2356-0304 (Paper) Vol. 3 No.2, Juli - Desember 2016

Luthans. Fred. 2015. Organizational Behavior, Mc Graw Hill, Inc,San fransisco, New York, USA.

Mangkunegara Anwar Prabu, 2012. Manajemen Sumber Daya Manusia Perusahaan, Cetakan Ketujuh, PT. Remaja Rosdakarya, Bandung.

Mahsun, Mohamad, 2016, Pengukuran Kinerja Sektor Publik, BPFE, Yogyakarta

Manik, 2014. Pengaruh Kompetensi Dan Kompensasi Terhadap Kepuasan Kerja Serta Implikasinya Pada Kinerja Paramedis Di Rumah Sakit Cibabat Kota Cimahi. Jurnal Ekonomi, Bisnis \& Entrepreneurship Vol. 8, No. 2, Oktober 2014, 62-72 ISSN 2443-0633

Nawawi, Hadiri. 2015, Manajemen Sumber Daya Manusia Untuk Bisnis Yang Kompetitif, Gajah Mada University Press, Cetakan Kedua, Yogyakarta.

Reza Amelia, 2013. Pengaruh Budaya Organisasi Dan Stres Kerja Terhadap Kinerja Pegawai Melalui Kepuasan Kerja Sebagai Variabel Intervening ( Studi Pada Bank Mandiri Cabang Padang). http://journal.fekon.unand.ac.id/ Jurnal FE. Universitas Andalas. Vol. 1 (2013) No. 1

Riduwan. 2015. Startegi Meningkatkan Kepuasan Pelanggan. Jakarta : Gramedia Pustaka Utama

Riyadi, 2017. Pengaruh Komunikasi, Motivasi Kerja Dan Kompetensi Terhadap Kepuasan Kerja Serta Implikasinya Pada Kinerja Dosen Pada Perguruan Tinggi Pariwisata Swasta Di Jawa Barat. Tourism and Hospitality Essentials (THE) Journal, Vol. 7, No. 2, 2017 - 73

Robbins, Stephen P. 2014. Perilaku Organisasi, Edisi kesepuluh, PT Indeks Jakarta.

Robbins, Stephen P, 2010. Organizational Behaviour Concepts, Controversies, Aplication, Egihth Edition, Prentice-Hall, Inc. New Jersey.

Rivai Veithzal, 2015. Perfomance Appraisal : Sistem yang tepat untuk menilai kinerja karyawan dan meningkatkan daya saing perusahaan. Jakarta: PT. Raja Grafindo Persada

Siagian, Sondang P, 2010. Teori Motivasi dan Aplikasinya. Rineka Cipta. Jakarta.

Simamora, H. 2008, Manajemen Sumber Daya Manusia, Second Edition, STIE YKPN, Jakarta.

Siswojo, 2010. Pengaruh Kepemimpinan, Motivasi, Kesejahteraan, Dan Kedisiplinan Terhadap Kinerja Perangkat Desa Di Kecamatan Kradenan Kabupaten Grobogan. Jurnal Manajemen Sumberdaya Manusia Vol. 4 No. 2 Desember 2010: 120 - 130

Sobariah dkk, 2018. Strategi Meningkatkan Kinerja Pegawai Dengan Disiplin Kerja Sebagai Variabel Intervening Di Kantor Kementerian Agama Kota Serang. Jurnal Riset Bisnis dan Manajemen Tirtayasa (JRBMT), Vol. 2 (1): hh.97-112 (Juni 2018) ISSN (Online) 2599-0837 
Excellent : Jurnal Manajemen, Bisnis dan Pendidikan

Vol 7, No 1 (2020) ; p.92-104; https://e-journal.stie-aub.ac.id/index.php/excellent

Sudarmanto, 2010. Kinerja dan Pengembangan Kopetensi SDM. Jogyakarta: Pustaka Pelajar.

Sedarmayanti. 2011. Manajemen Sumber Daya Manusia. Reformasi Birokrasi dan manajemen Pegawai Negeri Sipil. Jakarta. Refika Aditama.

Sugiyono, 2013. Metodologi Penelitian Bisnis. Bandung: Alfabeta

Sugiyono. 2010. Statistika untuk Penelitian. Bandung: Alfabeta.

Siagian, Sondang P, 2010. Teori Motivasi dan Aplikasinya. Rineka Cipta. Jakarta.

Suparta,2017. Pengaruh Kepemimpinan Dan Motivasi Ter- Hadap Kinerja Pegawai Melalui Mediasi Disiplin Kerja Pada Lpk Monarch Candidasa. JAGADHITA:Jurnal Ekonomi \& Bisnis, Vol. 4, No 1. Maret 2017, Hal 108-122

Slamet Riyadi, 2011. Pengaruh Kompensasi Finansial, Kepemimpinan dan Motivasi Terhadap Kinerja Pegawai pada Perusahaan Manufaktur di Jawa Timur. Jurnal Manajemen dan Kewirausahaan Vol. 13, No. 1, hal $40-45$.

Trishananto dkk, 2013. Pengaruh Kepemimpinan, Budaya Organisasi Dan Komitmen Organisasional Terhadap Kepuasan Kerja Guru Smkn 1 Klego Boyolali. Jurnal Manajemen Sumberdaya Manusia Vol. 7 No. 112 Juni 2013: 12 - 23

Wardhani, 2016. Pengaruh Kompensasi, Motivasi Dan Budaya Organisasi Terhadap Disiplin Kerja Pegawai Pt. Riau Pos Intermedia Pekanbaru. JOM Fekon Vol.3 No.1 (Februari) 2016

Veithzal Rivai, 2016. Kepemimpinan dan Perilaku Organisasi. Jakarta: PT. Raja Grafindo Persada.

Yukl, Gary A, 2012, "Managerial Leadership: A Review of Theory and Research", Journal of Management, Vol 15, No.2, 251-289. 